\title{
Ultrastructure of spermatozoa and spermiogenesis in Spirula spirula (L.): systematic importance and comparison with other cephalopods
}

\author{
John M. Healy \\ Department of Zoology, University of Queensland; St. Lucia 4067, Brisbane, Queensland, \\ Australia
}

\begin{abstract}
Spermatozoa and spermiogenesis in the deep-water cephalopod Spirula spirula (L.) are examined using transmission electron microscopy. Mature spermatozoa (taken from spermatophores) are elongate cells 115-120 $\mu \mathrm{m}$ long, composed of a conical acrosomal vesicle, cylindrical nucleus $(6.8-7 \mu \mathrm{m}$ long), flagellum and a loose mitochondrial sleeve - the latter concealing the proximal $6-8 \mu \mathrm{m}$ of the flagellum. The acrosomal vesicle is $2.8 \mu \mathrm{m}$ long with fibro-granular contents and an electron-lucent apical zone. Subacrosomal material, organized as closely packed granules, fills a basal invagination of the acrosomal vesicle. In early spermatids the flagellum is derived from a triplet substructure centriole positioned close to the developing nuclear invagination. As flagellum formation proceeds, the acrosomal vesicle (produced evidently through Golgi secretion) attaches to the condensing nucleus. Spermatids are connected by cytoplasmic bridges throughout their development, and exhibit a perinuclear sheath of microtubules from the onset of the fibrous stage of nuclear condensation (mid-, late spermatids). In mid-spermatids, mitochondria collect posterior to the nucleus and subsequently are packed into a cylindrical extension of the plasma membrane to form the periflagellar mitochondrial sleeve. These features of spermiogenesis and mature spermatozoa of Spirula clearly associate the Spirulidae with the Sepiida, Teuthida and Sepiolida particularly with the latter order. However, pending results of a thorough review of coleoid sperm morphology, the Spirulidae are here included in their own order - Spirulida (of Reitner \& Engeser, 1982 ) - rather than in either the Sepiida or Sepiolida.
\end{abstract}

\section{INTRODUCTION}

Spirula spirula (Linné) is a small meso- to bathypelagic cephalopod chiefly inhabiting tropical and sub-tropical regions of world oceans (Schmidt, 1922; Von Brunn, 1943; Clarke, 1970). The species, placed in its own family Spirulidae, is unique among living Cephalopoda in possessing a coiled, chambered, fully internal shell (Mutvei, 1964; Bandel \& Boletzky, 1979). Like the internal cuttlebones of sepiids or the external shell of Nautilus, the shell of Spirula serves a buoyancy function via the regulation of liquid within shell chambers by siphuncular tissues (Denton et al., 1967; Denton \& GilpinBrown, 1971).

The precise relationship of Spirula to other coleoid cephalopods is still debated. Generally, however, it is believed that the closest living relatives of Spirula are the Sepiidae, and in most classifications the Spirulidae are placed within the order Sepiida usually as a member family of the Sepioidea (e.g. Boss, 1982; Voss, 1977; Clarke \& Trueman, 1988). Recently, however, it has been suggested that the Spirulidae and/or 
Sepiolidae should be removed from the Sepiida and placed into separate orders (e.g. see Donovan, 1977; Fioroni, 1981; Reitner \& Engeser, 1982; Clarke, 1988). In a previous account (Healy, 1989), the author demonstrated that the ultrastructure of cephalopod sperm and spermatids has considerable potential as a taxonomic and phylogenetic indicator as in other molluscan classes. Although $S$. spirula is a common species and its shell is frequently washed ashore in large numbers, live or well-fixed specimens are rarely available for histological or TEM examination. The present study describes for the first time events of spermiogenesis and morphology of mature spermatophoral sperm of $S$. spirula using formalin fixed tissues. The data are firstly compared with those available for other cephalopod taxa and secondly discussed in relation to the systematic affinities of the Spirulidae.

\section{MATERIALS AND METHODS}

Spermatophores and testis tissue of Spirula spirula (Linné) were obtained from a seawater-formalin fixed specimen held in the wet collection of the Australian Museum Sydney (Registration number C.158 383). This specimen (Fig. 1A) was mid-water trawled east of Sydney at a depth of 636-647 m during March 1984 by the New South Wales State Fisheries research vessel "Kapala".

For transmission electron microscopy, testes tissue and the sperm-containing region of spermatophores were diced into $1-2 \mathrm{~mm}^{3}$ pieces, rinsed for $30 \mathrm{~min}$ in seawater, then placed into a $1 \%$ osmium tetroxide solution (prepared in seawater) for $80 \mathrm{~min}$. Following osmication, tissues were rinsed in seawater $(30 \mathrm{~min})$, dehydrated in a graded ethanol series and, finally, embedded in Spurr's epoxy resin. Semithin and ultrathin sections were cut using an LKB Ultrotome. Ultrathin sections were collected on uncoated copper grids, stained with $10 \%$ uranyl acetate $(20 \mathrm{~min})$ and Reynold's lead citrate $(10 \mathrm{~min})$ and examined with either Philips 300 or Hitachi 300 transmission electron microscopes.

\section{RESULTS}

\section{Spermatocytes}

Spermatocytes of Spirula are $8 \mu \mathrm{m}$ in diameter and contain a large ovoid nucleus (maximum diameter 5-6 $\mu \mathrm{m}$ ) showing prominent synaptinemal complexes (Fig. 1B). In comparison with the volume occupied by the nucleus, relatively little cytoplasm is present. Small round mitochondria are scattered throughout the cytoplasm together with at least one centriole.

Figs 1A-E. Spirula spirula. A: Dorsal view of Spirula spirula L. specimen used in this study (trawled at 636-647 $\mathrm{m}$ depth, east of Sydney). Note portion of chambered, internal shell (arrow) visible through broken skin $(\times 0.4)$. B: Survey section of testes showing spermatocytes $(1)$, early spermatids (2) and an advanced spermatid (3) ( $\times 4100)$. Inset: detail of synaptinemal complex from spermatocyte $(\times 10600)$. C: Early spermatid with centriole positioned at site of developing nuclear invagination $(\times 3500)$. D: Detail of centriole of Fig. 1C showing triplet substructure and satellite bodies (small arrows). Note developing nuclear invagination $(\times 39$ 000). E: Early spermatids linked by cytoplasmic bridges. Also visible, centriole/flagellum apparatus and attached acrosomal vesicle $(\times 9300)$. Abbreviations: av, acrosomal vesicle; br, cytoplasmic bridge(s); $c$ centriole; flagellum; $n$, nucleus 

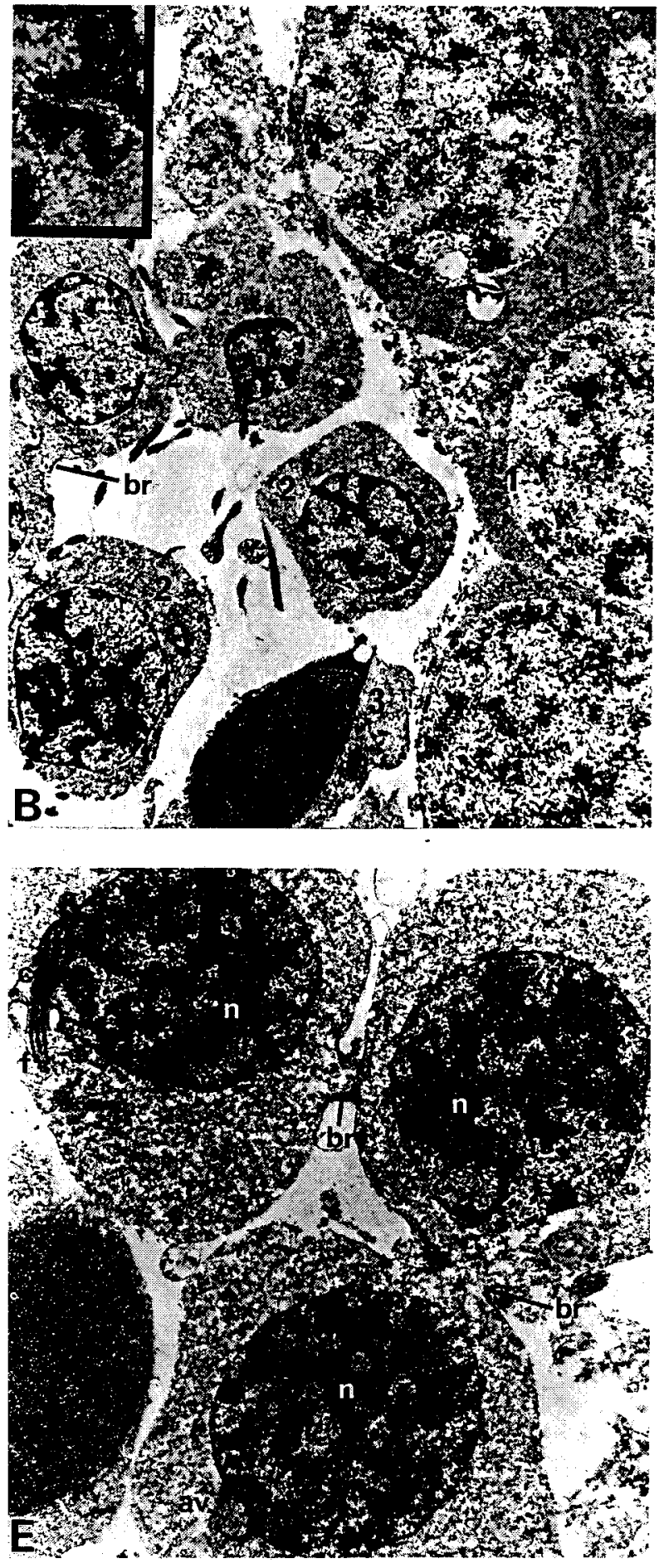
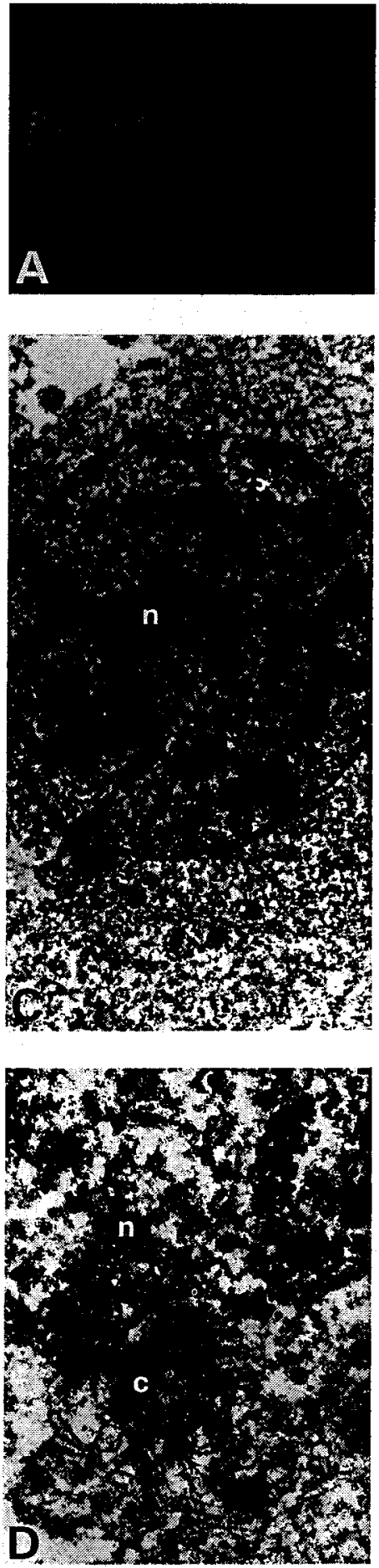


\section{Spermiogenesis}

\section{Early spermatids}

Early spermatids are round to ovoid and approximately $5 \mu \mathrm{m}$ in diameter. Nuclei of early spermatids are initially spherical, $3.3 \mu \mathrm{m}$ in diameter, and exhibit electron-dense tracts interspersed with coarsely granular patches (Figs 1C, E). Figures 1C, D show an early spermatid with a single triplet substructure centriole positioned at the entrance of the developing nuclear invagination. The triplets are embedded in a dense matrix and are also associated with nine satellite bodies apparently connected to the pericentriolar matrix (Fig. 1D). Early spermatids are interconnected by cytoplasmic bridges, each defined by a dense thickening of the plasma membrane (Fig. 1E). Although the initial stage of acrosome development was not traced, observations on later spermatids (e.g. Figs $2 B, D, E)$ suggest that the acrosomal vesicle is a product of Golgi activity. Figures $1 E$, $2 \mathrm{C}$ demonstrate that the acrosomal vesicle and the centriolar-flagellar apparatus attach to opposite extremities of the condensing (now pyriform) nucleus at the same time. Only a single centriole is present (Fig. 2A). An interesting feature of the newly attached centriolar-flagellar apparatus is its deviation by approximately $90^{\circ}$ from the longitudinal axis of the spermatid (Figs 1E, 2A, C). The reflected portion of the plasma membrane associated with the emergent flagellum becomes noticeably thickened and more electron-dense than adjoining areas (Figs $1 \mathrm{E}, 2 \mathrm{C}$ ).

\section{Mid-spermatids}

In mid-spermatids the nucleus initially retains the mottled appearance observed in early spermatids (Fig. 2D). Soon after the centriolar-flagellar apparatus reorientates parallel to the longitudinal axis of the spermatid (Fig. 2D), the nuclear fabric is converted first into a fine fibrous reticulum (Fig. 2E) and subsequently into longitudinally arranged fibres (Fig. 2F). A sheath of perinuclear microtubules anchored to the reflected plasma membrane also becomes evident (Fig. 2E). The Golgi complex continues its close association with the acrosomal vesicle - the latter now showing an electron-lucent apical zone and a flattened or slightly concave base (Figs 2E, F). Mitochondria migrate to the base of the nucleus (Fig. 2E) where collectively they will soon form the periflagellar mitochondrial sleeve of the mature spermatozoon.

Figs 2A-F. Spirula spirula. A: Centriole/flagellum apparatus attached to developing nuclear invagination $(\times 21300)$. B: Acrosomal vesicle attached to nucleus of early spermatid. Note Golgi complex $(\times 16800)$. C: Longitudinal section of spermatid showing relative positions of attached acrosomal vesicle, condensing nucleus and centriolar-flagellar complex $(\times 13300)$. D: Slightly later stage spermatid than Fig. 2C. Acrosomal vesicle and centriolar-flagellar complex are now longitudinally aligned with each other. Note also Golgi complex close to acrosomal vesicle, and the reflected plasma membrane around flagellum ( $\times 13250)$. E: Slightly more advanced spermatid than Fig. 2D. Acrosomal vesicle now shows electron-lucent apical zone (arrow). Golgi complex, cytoplasmic bridge and perinuclear microtubules also present ( $\times 13250)$. F: Acrosomal vesicle of mid-spermatid at fibrous stage of nuclear condensation. Note electron-lucent apex of vesicle (arrow) and plate substructure ( $\times 21600)$. Abbreviations: av, acrosomal vesicle; br, cytoplasmic bridge; $\mathrm{c}$, centriole; $\mathrm{f}$, flagellum; G, Golgi complex; m, mitochondria; mt, microtubules; n, nucleus; p, plates of acrosomal vesicle 




\section{Late spermatids}

In late spermatids the fibres of the condensing nucleus thicken through lateral fusion (Figs 3A, B) while the perinuclear microtubules (Fig. 3B) extend posteriorly into the developing mitochondrial sleeve (Fig. 3D). Mitochondria contained within the developing mitochondrial sleeve retain their individuality and unmodified cristae. During this final stage of spermiogenesis, cytoplasm migrates posteriorly and is ultimately sloughed. As the acrosomal vesicle elongates, its now well-developed basal invagination fills with a fibrous subacrosomal deposit (Fig. 3C). The electron-lucent zone and internal plates of the acrosomal vesicle are retained (Figs $3 C, F$ ). Gradually, the nucleus loses its fibrous substructure, decreases in diameter (from $2.8 \mu \mathrm{m}$ to $1.9 \mu \mathrm{m}$ ) and in almost mature sperm appears uniformly electron-dense, save for occasional spaces (Fig. 3F).

Figure 4 summarizes in semi-diagrammatic form the structure of spermatocytes and events of spermiogenesis in Spirula spirula.

\section{Mature spermatozoa}

Mature spermatozoa from spermatophores consist of an acrosomal complex, nucleus, flagellum and a periflagellar mitochondrial sleeve which encloses the proximal 6-8 $\mu \mathrm{m}$ of the flagellum (Figs 5A, B).

The acrosomal vesicle is $2.8 \mu \mathrm{m}$ long with a $1 \mu \mathrm{m}$ deep basal invagination filled by closely packed granules (Figs 5 C, D, E). Contents of the acrosomal vesicle form a fibrous reticulum with the exception of the apical region which is apparently empty (Figs $5 \mathrm{~A}-\mathrm{E}$ ). Angularly orientated plates line the inner surface of the acrosomal vesicle (Fig. 5D).

The nucleus is cylindrical, 6.8-7 $\mu \mathrm{m}$ long, and uniformly electron-dense (Figs 5A). A shallow $(0.6 \mu \mathrm{m}$ deep) basal invagination forms the anchorage point for the centriolar/ flagellar complex (Figs 5C, F). No evidence of nuclear cavities or fibrous substructure (both evident in spermatids - see Figs $3 \mathrm{~A}-\mathrm{F}$ ) could be detected in mature sperm nuclei. Longitudinal sections (e.g. Figs $5 \mathrm{~A}, \mathrm{~F}$ ) show that the basal invagination of the nucleus is eccentrically positioned.

Posterior to the nucleus, a loose mitochondrial sleeve envelops the proximal $6-8 \mu \mathrm{m}$ of the sperm flagellum (Fig. 5B). The sleeve consists of numerous, cristate mitochondria and dense (?glycogen) granules packed within a skirt-like extension of the plasma membrane (forming a cylindrical pocket) (Figs 5B, C, F-H). The flagellum is approximately $100 \mu \mathrm{m}$ long and composed of a $9+2$ axoneme surrounded by nine coarse fibres $(30 \times 80 \mathrm{~nm}$ in transverse section), the plasma membrane (with prominent glycocalyx)

Figs 3A-F. Spirula spirula. A: Transverse section through late spermatid nucleus showing thick fibres and perinuclear microtubules $(\times 22500)$. B: Detail of perinuclear microtubules $(\times 54500)$. C: Acrosomal complex of late spermatid. Note electron-lucent apex (arrow), internal plates and subacrosomal material $(\times 17700)$. D: Longitudinal section showing centriole lodged in nuclear invagination, flagellum, mitochondrial sleeve and microtubules $(\times 27700)$. E: Longitudinal section of late spermatid showing complete nucleus, base of acrosome, microtubules and proximal portion of mitochondrial sleeve and flagellum $(\times 14000)$. F: Acrosome and nucleus of almost mature spermatozoon. Arrow indicates electron-lucent apex of acrosome $(\times 11000)$. Abbreviations: av, acrosomal vesicle; $c$, centriole; f, flagellum; mt, microtubules; $n$, nucleus; $p$, plates of acrosomal vesicle; sl, mitochondrial sleeve; sm, subacrosomal material 

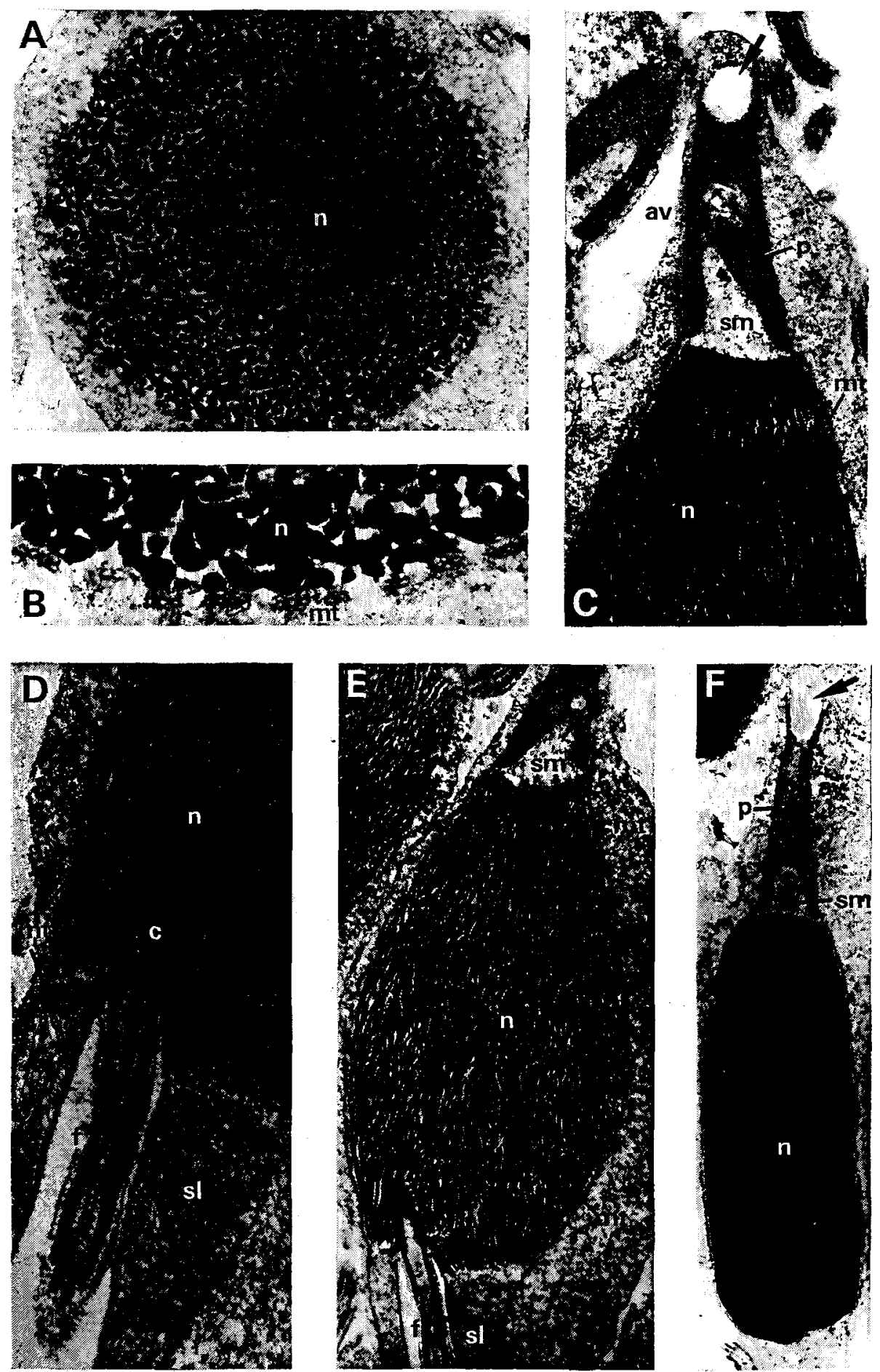
and the mitochondrial sleeve. Figures $5 \mathrm{~B}, \mathrm{H}$ show that the sleeve, at its posterior extremity, does not fully enclose the flagellum.

Posterior to the mitochondrial. sleeve, coarse fibres of the flagellum gradually decrease in diameter and are eventually lost (Figs 5I [1-5]). Dense granules (?glycogen) occur between coarse fibres (see Fig. 5 [ [4]). Distally, the flagellar axoneme degenerates into singlet microtubules (Fig. 5I [6]).

\section{DISCUSSION}

\section{Spermiogenesis}

A number of spermiogenic features of Spirula spirula (for example, early stages of acrosome formation, nuclear condensation with perinuclear microtubules) have been observed in other cephalopod species (Galangau, 1969; Maxwell, 1974, 1975; Healy, 1989, 1990): in particular, the pattern of development resembles that described by Maxwell (1975) for members of the Sepiida and Teuthida. Spirula, however, differs from the Sepiida and Teuthida in the formation of a periflagellar mitochondrial sleeve rather than a mitochondrial spur and in the production of a more slender acrosomal vesicle (showing a clearly differentiated apical zone - also observed in sperm acrosomes of Sepiolida - see Fig. 6). A periflagellar mitochondrial sleeve has also been demonstrated in the sepiolid Heteroteuthis sp. (see Fig. 6), but at present no information is available on its formation during spermiogenesis (in other investigated sepiolids - Sepietta oweniana and Rossia pacifica, a mitochondrial spur of the Sepiida/Teuthida type is present Franzén, 1955; Fields \& Thompson, 1976). Although the microtubular sheath in spermatids of Spirula encloses the developing nucleus and mitochondrial sleeve, in other cephalopods this sheath appears to be confined to the nuclear region (Maxwell, 1974, 1975; Healy, 1990). Available tissues of Spirula were not fixed well enough to determine whether or not cross-linkages between microtubules (noted in Nautilus and some coleoids - Arnold \& Williams-Arnold, 1978; Bergstrom \& Arnold, 1974; Maxwell, 1974) were present.

\section{Mature spermatozoa: comparison with other cephalopods}

Figure 6 summarizes, in semi-diagrammatic form, sperm morphology in Spirula and other studied coleoid taxa (based on data of Franzén, 1955, 1967; Galangau, 1969;

Figs 4A-F. Semi-diagrammatic summary of spermiogenesis and mature sperm of Spirula spirula. A: Spermatocyte with synaptinemal complexes (arrows) (×6750). B: Early spermatids linked by cytoplasmic bridges $(\times 6750)$. C: Mid-spermatid showing relative positions of attached acrosomal vesicle, centriolar-flagellar apparatus and condensing nucleus. Note also cytoplasmic bridge $(\times 8300)$. D: Mid spermatid after realignment of acrosome and centriolar-flagellar apparatus into longitudinal axis. Microtubular sheath associated with nucleus and mitochondrial sleeve $(\times 8300)$. E: Advanced spermatid with development of the acrosomal complex and mitochondrial sleeve almost complete $(\times 8300)$. F: Mature spermatozoon $(\times 8300)$. Abbreviations: av, acrosomal vesicle; br, cytoplasmic

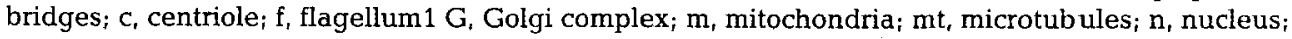
$\mathrm{p}$, internal plates of acrosomal vesicle; pm, plasma membrane; sl, mitochondrial sleeve; $\mathrm{sm}_{\text {, }}$ subacrosomal material 

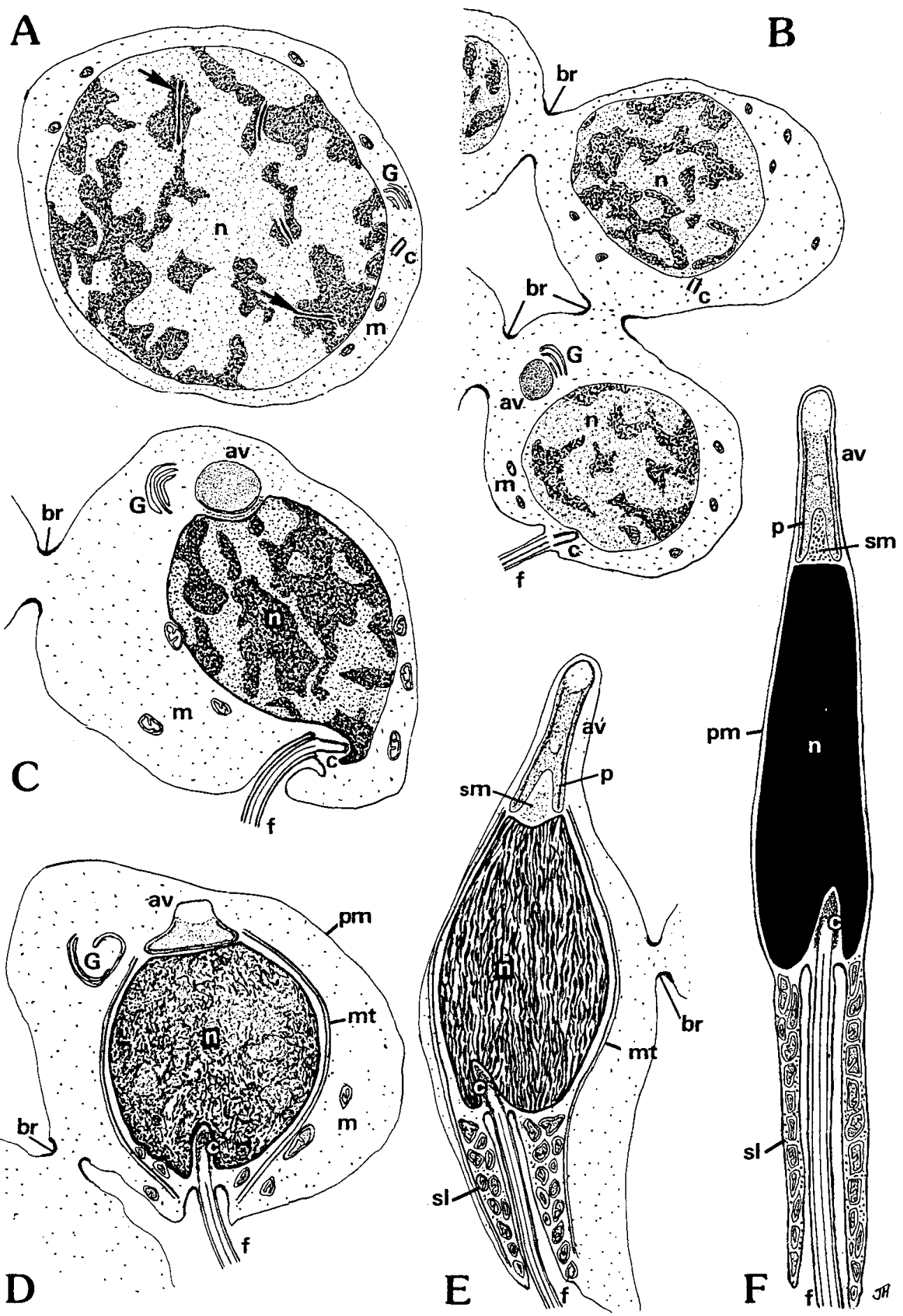
Galangau \& Tuzet, 1968a, b; Longo \& Anderson, 1970; Maxwell, 1974, 1975; Fields \& Thompson, 1976; Olson \& Linck, 1980; Healy, 1989, 1990 and unpublished data).

It can be seen from this comparative figure that sperm of the Sepiidae, Loliginidae and Sepiolidae (exception Heteroteuthis) all share a curved nucleus, eccentrically positioned flagellum and mitochondrial spur and a plasma membrane skirt. Acrosomal vesicles of Sepiidae and Loliginidae are dome-shaped structures in contrast to those of the Sepiolidae and Spirula which are relatively narrow with a pronounced, electronlucent apical zone (an apical zone is present in acrosomes of Sepiida and Teuthida, but is poorly differentiated) (Fig. 6). Acrosomal vesicles of all decapod coleoids (including Spirula) show variously developed rods or plates - usually angularly oriented in relation to the longitudinal axis (see also Fields \& Thompson, 1976 and Olson \& Linck, 1980). Olson \& Linck (1980) found that each internal "fibre" (= rod) of the acrosomal vesicle of Loligo pealeii was associated spatially with a small deposit of dense material lying between the plasma and vesicle membranes. It was not possible to determine whether such deposits occur in the acrosomal region of Spirula in the material examined. Until an investigation of the acrosome reaction is carried out, the function of rods/plates in sepid/ teuthid/Spirula acrosomes can only be surmised. Possibly, these structures serve as internal supports for the acrosomal vesicle. Spermatozoa of Spirula differ from most other decapod coleoids in possessing a straight nucleus and a periflagellar mitochondrial sleeve. A similar nucleus and sleeve are present in spermatozoa of the sepiolid Heteroteuthis sp. (see Fig. 6), perhaps indicating a relationship between Spirulidae and Sepiolidae (otherwise suggested by acrosomal morphology). It seems reasonable to suggest that the straight nucleus and mitochondrial sleeve of Spirula and Heteroteuthis have been derived from the curved nucleus and mitochondrial spur (respectively) seen in the Sepiidae, Loliginidae and the sepiolids Rossia pacifica and Sepietta oweniana. Similarly, the acrosomal vesicles of Spirula and sepiolids are clearly more complex, elongate versions of the dome-shaped acrosomes of sepiid and loliginid spermatozoa.

Spermatozoa of Vampyroteuthis exhibit several characters commonly noted in spermatozoa of externally fertilizing (often primitive) molluscs such as the Archaeogastropoda, Bivalvia and Scaphopoda (relatively undifferentiated acrosomal vesicle; two triplet substructure centrioles; short nucleus; pericentriolar mitochondria) (Fig. 6; Healy, $1989,1990)$. In addition, one significant advanced character is also present in Vampy-

Figs 5A-F. Mature spermatozoa of Spirula spirula (ex spermatophores). A: Longitudinal section through acrosomal complex, nucleus and proximal portion of mitochondrial sleeve $(\times 11400)$. B: LS base of nucleus and entire mitochondrial sleeve $(\times 11400)$. C: LS acrosomal complex (arrow indicates electron-lucent apex of acrosomal vesicle) and mitochondrial sleeve ( $\times 13$ 300). D: LS acrosomal vesicle (oblique anteriorly). Contents of the vesicle form a fibrous reticulum. Subacrosomal material organized as densely packed granules $(\times 27000)$. E: TS base of acrosome $(\times 26000)$. F: LS nuclear invagination (with embedded centriole) and mitochondrial sleeve. Dense (?glycogen) granules are packed in between mitochondria $(\times 26500)$. G: TS mitochondrial sleeve showing mitochondria, dense granules, axoneme of flagellum, coarse fibres, glycocalyx $(\times 52000)$. $\mathrm{H}$ : TS terminal region of mitochondrial sleeve $(\times 52000)$. I: TS flagella. Note $9+2$ axoneme with accompanying nine coarse fibres and dense (?glycogen) granules (series 1-6 showing diminution and eventual loss of coarse fibres) $(\times 68000$ ). Abbreviations: a, acrosomal complex; av, acrosomal vesicle; ax, axoneme; $c$, centriole; $c f$, coarse fibres; f, flagellum; $g$, dense (?glycogen) granules; $g c_{\text {, }}$ glycocalyx; $n$, nucleus; $p$, internal plates of acrosomal vesicle; sl, mitochondrial sleeve; sm, subacrosomal material 

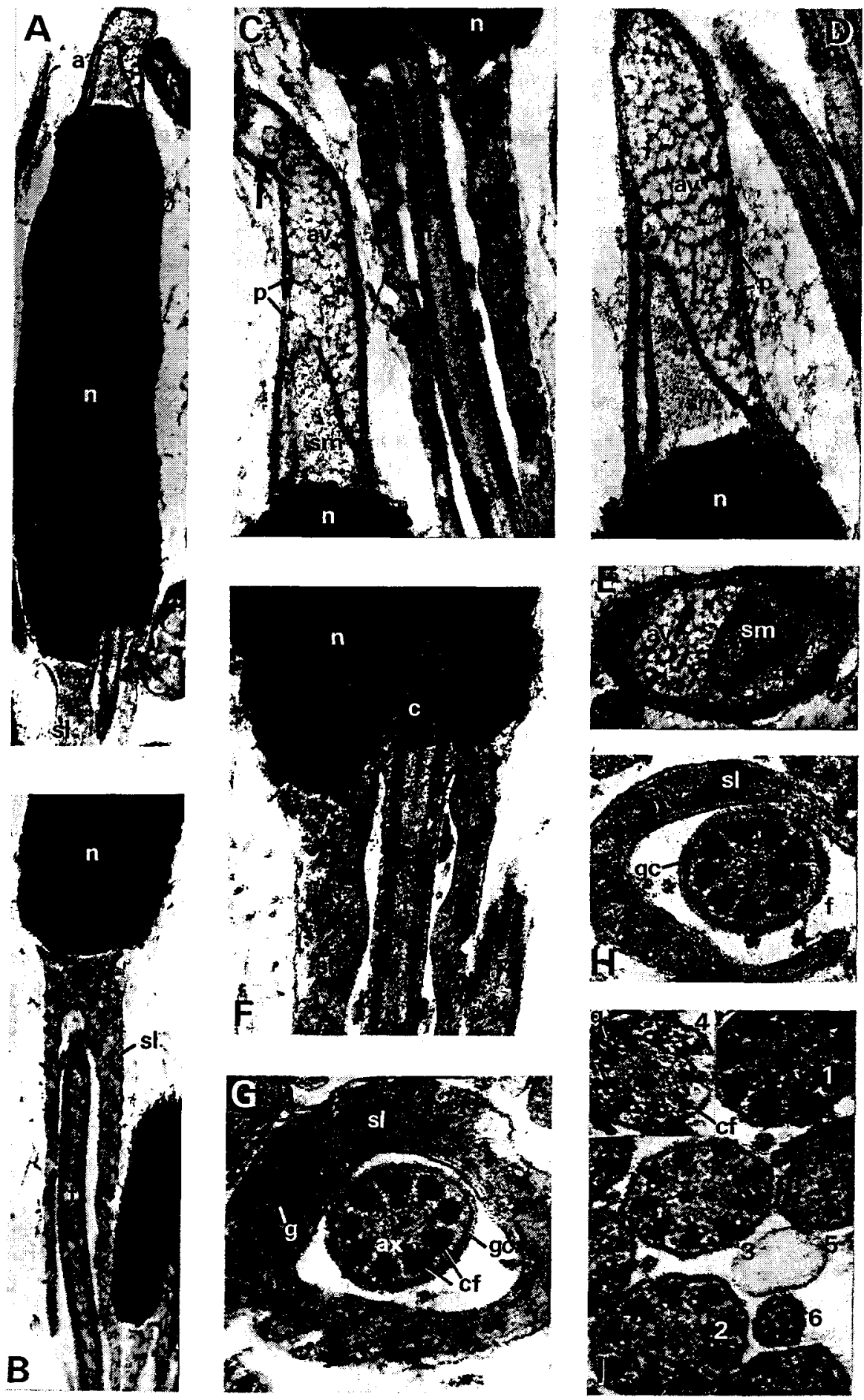
roteuthis spermatozoa, namely an extensive dense plug within the nuclear invagination, elsewhere reported only in incirrate Octopoda (Fig. 6; see also Healy, 1989, 1990).

Sperm morphology in the Octopoda (data only available for suborder Incirrata) is variable, though consistently different from the Sepiida/Sepiolida/Teuthida. Acrosomes are either straight with periodic banding and a helical keel (Octopus - Fig. 6; Galangau \& Tuzet 1968a; Longo \& Anderson, 1970; Healy, 1989) or helically coiled without internal substructure (Eledone - Fig. 6; Maxwell, 1974). Nuclei are filiform and sometimes helically coiled (Fìg. 6; Franzén, 1967; Galangau, 1969; Longo \& Anderson, 1970; Maxwell, 1974; Healy, 1989). Mitochondria enclose the axoneme/coarse fibre complex to form a true midpiece rather than a mitochondrial spur or a loose periflagellar sleeve (Fig. 6; Galangau \& Tuzet, 1968b; Longo \& Anderson, 1970; Maxwell, 1974; Healy, 1989). A membrane skirt ("annulus" of Longo \& Anderson, 1970) occurs at the junction of midpiece and glycogen piece. It is probably homologous with the membrane skirt of most other coleoid sperm and the mitochondrial sleeve of Spirula and Heteroteuthis (interestingly, while a skirt is present in Nautilus [Arnold \& Williams-Arnold, 1978], it is absent in Vampyroteuthis [Fig. 6; Healy, 1989, 1990]).

\section{Systematic considerations}

There are widely differing opinions concerning the interrelationships between living coleoids (Sepiida, Sepiolida, Teuthida, Octopoda, Vampyromorpha) and extinct coleoids such as the Belemnitida, Phragmoteuthida, Belemnoteuthida and Loligosepiidae (Jeletzky, 1966; Donovan, 1977; Teichert, 1988; Reitner \& Engeser, 1982; Bandel, 1985; Bandel \& Leich, 1986; Clarke, 1988). The discovery or re-study of coleoid fossils showing soft part impressions has helped to clarify some issues such as the status of teuthid-like forms Trachyteuthis and Plesioteuthis (transferred to Vampyromorpha by Bandel \& Leich, 1986) but has complicated other problems such as the origin of Teuthida, Sepiida and Octopoda (see Donovan, 1977; Engeser, 1988).

Even in the absence of sperm data for important living groups of coleoids (e.g. oegopsid Teuthida, cirrate and some incirrate Octopoda, some Sepiida and Sepiolida), Figure 6 clearly indicates a close relationship between the Sepiida, Teuthida and Sepiolida. Of these three orders, spermatozoa of Spirula appear closest to those of sepiolids (acrosomal morphology; periflagellar mitochondrial sleeve of Spirula also seen in sepiolid Heteroteuthis sp.). Major differences between spermatozoa of Vampyromorpha/Octopoda on the one hand and the Sepiida/Teuthida/Sepiolida on the other suggest that these two clades diverged at an early stage in the history of the Coleoida, before the distinctive decapodan sperm type (featuring a curved nucleus, eccentrically positioned flagellum and mitochondrial spur) had evolved. Such a conclusion is in total

Fig 6. Semi-diagrammatic summary of sperm morphology in the Coleoidea. Sources of data: Eusepia, Alloteuthis, Loligo Maxwell (1975); Loligo Olson \& Linck, 1980; Rossia (Fields \& Thompson, 1976); Sepia, Heteroteuthis (Healy unpublished data); Spirula - (present study); Vampyroteuthis (Healy, 1989, 1990); Octopus (Galangau \& Tuzet, 1968a, b; Galangau, 1969; Longo \& Anderson, 1970; Healy, 1989, 1990); Eledone (Maxwell, 1974). Ultrastructure of Sepietta spermatozoa inferred from light microscopic data of Franzén (1955). Scale bar $=2 \mu \mathrm{m}$. Abbreviations: av, acrosomal vesicle; c, centriole(s); dp, dense plug; f, flagellum; $m$, mitochondrion; $m$, mitochondrial spur; $n$, nucleus; s, membrane skirt; sh, midpiece sheath; sl, periflagellar mitochondrial sleeve 
SEPIIDA TEUTHIDA VAMPYROMORPHA OCTOPODA
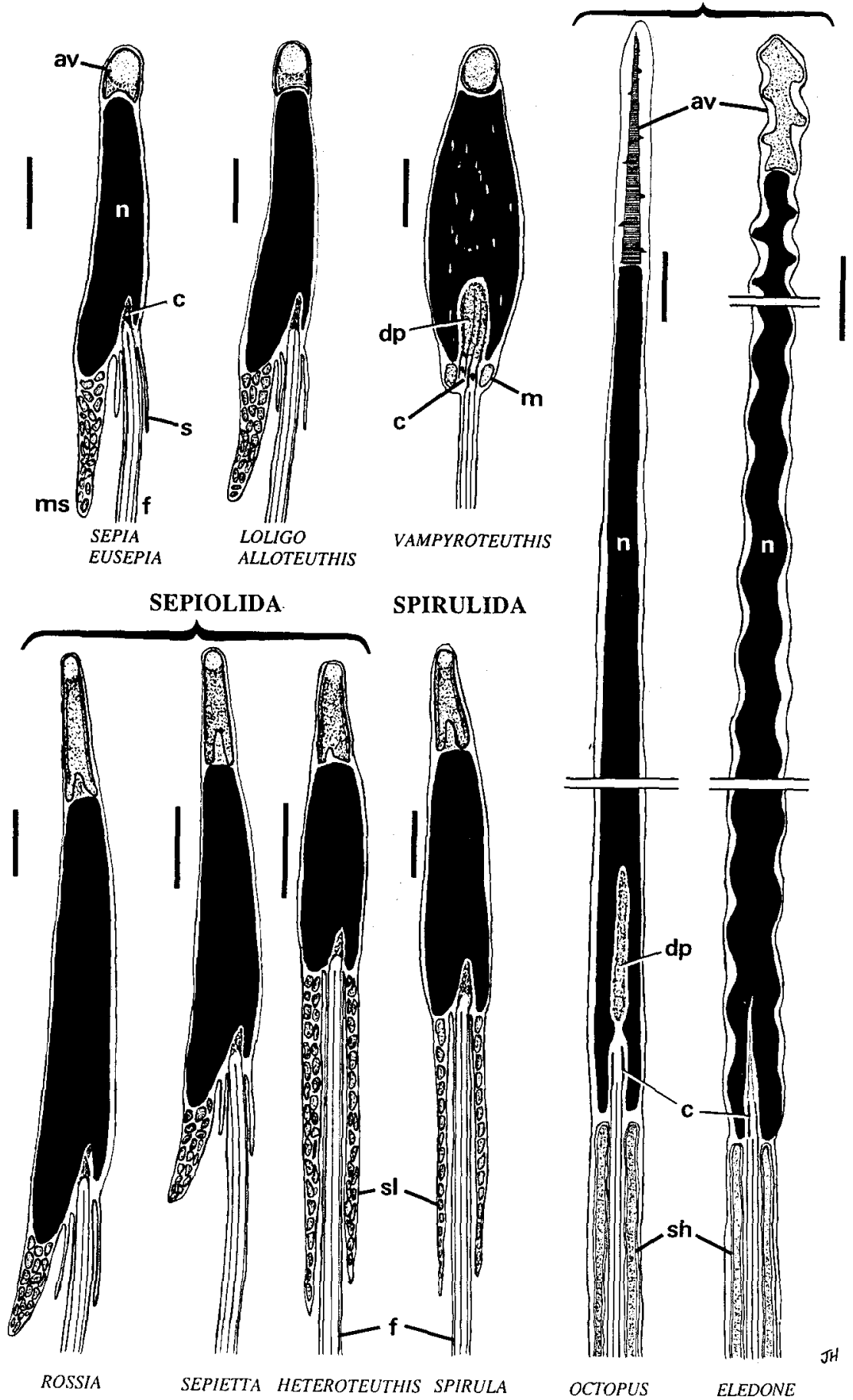
accord with the comment by Fields \& Thompson (1976, p. 917) that it was difficult to envisage derivation of octopodan sperm from those of decapods and that "the sperm of cephalopods ancestral to both groups may have been closer to the octopodan than to the decapodan pattern".

Since the Sepiolidae have now been separated from the Sepiida as a new order Sepiolida (see Fioroni, 1981; Clarke, 1988; Clarke \& Trueman, 1988), the question then arises as to whether or not Spirula (and Spirulidae) should also be placed in a separate order (Spirulida of Reitner \& Engeser, 1982). Palaeontological evidence indicates that there are reasonable grounds for doing this (Donovan, 1977; Reitner \& Engeser, 1982) and certainly sperm morphology suggests that the Spirulidae are closer to sepiolids than sepiids. For the present, the author accepts Reitner \& Engeser's order Spirulida as a useful collective group for living Spirula (Spirulidae) and its presumed belemnomorph antecedents (e.g. Spirulirostridae, Groenlandibelidae). Further research on spermatozoa and spermiogenesis will undoubtedly assist in defining relationships within the Coleoidea, and, possibly, lead to a better understanding of the phylogenetic position of this subclass within the Cephalopoda.

Acknowledgements. I thank the following people for facilitating this research. I. Loch allowed me access to seawater-formalin preserved Spirula spirula L. held in the wet collection of the Australian Museurn (Sydney). Professor B. G. M. Jamieson critically read the original manuscript. Dr. D. Cockayne and his staff at the Electron Microscope Unit of the University of Sydney kindly provided technical assistance with TEM as did L. Daddow (University of QLD). Professor D. T. Anderson FRS AO, Professor B. G. M. Jamieson and Dr. W. F. Ponder are thanked for their encouragement during my postdoctoral fellowships at the University of Sydney (Farrand Memorial Research Fellowship) and University of Queensland. The project was supported financially by the Joyce Vickery Research Fund of the Linnean Society of New South Wales and a Special Projects Grant from the University of Queensland.

\section{LITERATURE CITED}

Arnold, J. M. \& Williams-Arnold, L. D., 1978. Spermiogenesis of Nautilus pompilius. I. General survey. - J. exp. Zool. 205, 13-26.

Bandel, K., 1985. Cephalopod morphology and function. In: Mollusks. Ed. by T. W. Broadhead. Univ. Tennessee, Dept. Geol. Sci., Knoxville, 190-203.

Bandel, K. \& Boletzky, S. von, 1979. A comparative study of the structure, development and morphological relationships of chambered cephalopod shells. - Veliger 21, 313-354.

Bandel, K. \& Leich, H., 1986. Jurassic Vampyromorpha (dibranchiate cephalopods). - N. Jb. Geol. Paläont. Mh. 3, 129-148.

Bergstrom, B. H. \& Arnold, J. M., 1974. Nonkinetochore association of chromatin and microtubules: a preliminary note. - J. Cell Biol. 62, 917-920.

Boss, K. J., 1982. Mollusca. In: Synopsis and classification of living organisms. Ed. by S. P. Parker. McGraw-Hill, New York, 2, 945-1166.

Brunn, A. Fr, von, 1943. The biology of Spirula spirula (L.). - Dana Rep. 24, 1-46.

Clarke, M. R., 1970. Growth and development of Spirula spirula. - J. mar. biol. Ass. U. K. 50, $53-64$.

Clarke, M. R., 1988. Evolution of Recent cephalopods - a brief review. In: The Mollusca. Ed. by M. R. Clarke \& E. R. Trueman. Acad. Press, New York, 12, 331-340.

Clarke, M. R. \& Trueman, E. R., 1988. Introduction. In: The Mollusca. Ed. by M. R. Clarke \& E. R. Trueman. Acad. Press, New York, 12,1-10.

Denton, E. J. \& Gilpin-Brown, J. B., 1971. Further observations on the buoyancy of Spirula - J. mar. biol. Ass. U. K. 51, 363-373.

Denton, E. J., Gilpin-Brown, J. B. \& Howarth, J. V., 1967. On the buoyancy of Spirula spirula. - J. mar. biol. Ass. U. K. 47, 181-191. 
Donovan, D. T., 1977. Evolution of the dibranchiate Cephalopoda. In: The biology of cephalopods. Ed. by M. Nixon \& J. B. Messenger. Acad. Press, New York, 15-48.

Engeser, T. S., 1988. Fossil "octopods" - a critical review. In: The Mollusca. Ed. by M. R. Clarke \& E. R. Trueman. Acad. Press, New York, 12, 81-87.

Fields, W. G. \& Thompson, K. A., 1976. Ultrastructure and functional morphology of spermatozoa of Rossia pacifica (Cephalopoda, Decapoda). - Can. J. Zool. 54, 908-932.

Fioroni, P., 1981. Die Sonderstellung der Sepiolen, ein Vergleich der Ordnungen der rezenten Cephalopoden. - Zool. Jb. (Abt. Syst. Ökol. Geogr. Tiere) 108, 178-228.

Franzén, A., 1955. Comparative morphological investigations into the spermiogenesis among Mollusca. - Zool. Bidr. Uppsala 30, 399-456.

Franzén, A., 1967. Spermiogenesis and spermatozoa of the Cephalopoda. - Ark. Zool. 19, 323-334.

Galangau, M. V., 1969. Etude en microscope électronique de la gamétogenèse de Milax gagates Drap. (Gastéropodes, Pulmonés, Limicidae). Evolution des ultrastuctures au cours de la spermatogénèse chez différents types de Mollusques. Thése Univ. de Montpellier, 152 pp.

Galangau, V. \& Tuzet, O., 1968a. L'acrosome d' Octopus vulgaris Lmk. Observations au microscope électronique. - C. r. hebd. Séanc. Acad. Sci., Paris (D) 267, 1462-1467.

Galangau, V. \& Tuzet, O., 1968b. Les mitochondries pendant la spermatogenése d'Octopus vulgaris Lmk. Recherches au microscope électronique. - C. r. hebd. Séanc. Acad. Sci., Paris, (D) 267 , 1735-1737.

Healy, J. M., 1989. Spermatozoa of the deep-sea cephalopod Vampyroteuthis infernalis Chun: ultrastructure and possible phylogenetic significance. - Phil. Trans R. Soc. 323, 589-600.

Healy, J. M., 1990. Ultrastructure of spermiogenesis in Vampyroteuthis infernalis Chun, a relict cephalopod mollusc. - Helgoländer Meeresunters. 44, 95-107.

Jeletzky, J. A., 1966. Comparative morphology, phylogeny and classification of fossil Coleoidea. Paleont. Contr. Univ. Kans. 7, 1-162.

Longo, F. J. \& Anderson, E., 1970. Structural and cytochemical features of the sperm of the cephalopod Octopus bimaculatus. - J. Ultrastruct. Res. 32, 94-106.

Maxwell, W. L., 1974. Spermiogenesis of Eledone cirrhosa Lamarck (Cephalopoda, Octopoda). Proc. R. Soc. Lond. (B) 186, 181-190.

Maxwell, W. L., 1975. Spermiogenesis of Eusepia officinalis (L.), Loligo forbesi (Steenstrup) and Alloteuthis subulata (L.) (Cephalopoda, Decapoda). - Proc. R. Soc. Lond. (B) 191, 527-535.

Mutvei, H., 1964. On the shells of Nautilus and Spirula with notes on the shell secretion in noncephalopod molluscs. - Ark. Zool. 16, 221-278.

Olson, G. E. \& Linck, R. W., 1980. Membrane differentiations in spermatozoa of the squid, Loligo pealeii. - Gamete Res. 3, 329-342.

Reitner, J. \& Engeser, T., 1982, Phylogenetic trends in phragmocone-bearing coleoids (Belemnomorpha). - N. Jb. Geol. Paläont. Abh. 164, 156-162.

Schmidt, J., 1922. Live specimens of Spirula. - Nature, Lond. 110, 788-790.

Teichert, C., 1988. Main features of cephalopod evolution. In: The Mollusca. Ed. by M. R. Clarke \& E. R. Trueman. Acad. Press, New'York, 12, 11-79.

Voss, G. L., 1977. Classification of Recent Cephalopoda. Appendix II. In: The biology of cephalopods. Ed. by M. Nixon \& J. M. Messenger. Acad. Press, New York, 575-579. 